\title{
Developing Students' Global Awareness in EFL Reading and Speaking
}

\author{
Prof. Reima Al-Jarf ${ }^{1 *}$ (iD \\ ${ }^{\mathrm{T}}$ King Saud University, Riyadh, Saudi Arabia, ORCID ID: 0000-0002-6255-1305 \\ *Corresponding Author: Reima Al-Jarf \\ King Saud University, Riyadh, Saudi Arabia
}

\section{Article History}

Received: 17.02 .2022

Accepted: 24.02.2022

Published: 26.02.2022

\begin{abstract}
Results of a questionnaire with a sample of EFL instructors at some Saudi universities showed that the instructors just follow the assigned textbook and do not integrate any global themes in their EFL courses. Therefore, this article aims to proposes a model for integrating global themes in the EFL college classroom, especially in reading and speaking instruction. The aim of the model is to help EFL students learn about the ideologies, cultures and customs of other countries; address current global problems; compare the similarities and differences the peoples of the world share; focus on the interrelatedness of human beings; recognize stereotypes western people have about Islam, Muslims, Arabs, women; and listen to multiple perspectives. The model proposes 4 areas of global themes that can be integrated in EFL reading and speaking: (i) global systems (political, economic, cultural, ideological, ecological, health, social, technological, educational, ideological and judicial; (ii) diverse human values such as conflict resolution, cooperation and teamwork; (iii) current global issues issues (terrorism, fundamentalism, violence...etc); and (iv) the history of contact and interdependence among peoples. It also proposes the integration of 4 types of goals: knowledge, skills, values and participation goals. Examples of concepts, and types of objectives related to the global themes, resources for locating global themes; stages of teaching the global themes and instructor's role are provided.
\end{abstract}

Keywords: Global awareness, global themes, intercultural competence, EFL instruction, global education, global systems, Saudi freshman students.

\section{INTRODUCTION}

According to Bloomsburg University of Pennsylvania, global awarenes ${ }^{1}$ is understanding global social, cultural, economic, political, and environmental issues, rising global problems such as pandemics, economic recessions, poverty, and immigration. It helps us understand the similarities and differences among people, the effect of globalization, crosscultural understanding and better partnerships among governmental organizations, educational institutions, and businesses in an effort to solve global issues. Solving global issues requires awareness and collaborative efforts towards global peace, global diversity in life experiences, family situations, age, gender, cognitive ability, ethnicity, race, culture, and religion. In education ${ }^{2}$, global awareness aims to create global citizens who are open to those coming from different cultures, countries, and religious backgrounds. It involves teaching students about different cultures, their civic rights, and duties locally and globally. The ability to understand, cooperate, respect and work with people from different cultural backgrounds has become important for academic and social success in an interconnected world.

Due to the importance of global awareness in education, a review of the literature showed numerous studies that explored different aspects of global awareness. The first line of research showed the benefits of raising students' global awareness in language teaching and learning. In this respect, Aubrey (2009) indicated that creating a global cultural

\footnotetext{
${ }^{1}$ What Is the Meaning of Global Awareness? (reference.com)

${ }^{2}$ What is Global Awareness and Why Does it Matter? - FPU (fresno.edu)
}

Copyright (C) 2022 The Author(s): This is an open-access article distributed under the terms of the Creative Commons Attribution 4.0 International License (CC BY-NC 4.0) which permits unrestricted use, distribution, and reproduction in any medium for noncommercial use provided the original author and source are credited. 
consciousness among second language (L2) students can help bridge the gap between linguistic ability and functional intercultural communication. Zhu (2011) added that the incorporation of culture in English-as-a-foreign-language (EFL) teaching and learning, with a focus on the cultivation of culturally empathic ability develop Chinese students' intercultural empathy. The integration of content-based, task-based, and communicative language teaching methods resulted in higher levels of awareness of global issues and better ability to analyze problems and apply critical thinking by intermediate students at the Institute of Language Studies, in India. The students were also more effective and coherent in their EFL class participation than other classes. Those strategies helped enhance global awareness and the linguistic competence of students (Omidvar \& Sukumar, 2013). Cultural knowledge promoted Iranian EFL students' listening comprehension proficiency (Hayati, 2009).

Furthermore, the integrating global issues and language education revealed positive opinions about the effects of dealing with global issues in class such as problems of poverty, wars, environmental destruction, climate change, pandemics, gender inequality, hunger, and oppression. Such issues expanded students' perspectives and improved their language learning gains. The integration of global issues and language education equipped the students with the knowledge, skills, and ability to effectively communicate in the foreign language, enabled them to be socially conscious of global problems and provided them with linguistic tools to take action (Bayraktar Balkir, 2021). Similarly, Zhang, Cui \& Zhang (2021) found a relationship between multicultural awareness and language development among EFL freshman students in China, who received multicultural counselling training. The students had positive attitudes towards multicultural differences. However, the students did not seem to be confident about dealing with multicultural situations in real life. Multicultural awareness measurements did not contribute to EFL skills in a short period of time, but its contribution was more noticeable after a whole academic year. Moreover, blogging about current global events in the EFL writing classroom had positive effects on Saudi EFL freshman students' writing skill improvement, global awareness and attitudes (Al-Jarf, 2022a).

Another group of studies focused on teaching and learning strategies for expanding global awareness and understanding of cultural sensitivity in students through global consumer exchange (Lopez, Kemp \& McKenzie, 2019); short-term study abroad (DeLoach, Kurt \& Olitsky, 2015); study abroad, service-learning, community service, and cultural coursework (Welton, 2021); study abroad and literature study as methods of internationalization (Medina \& Kiefel, 2021); art, music and politics (Gertsenzon, 2021); incorporating cultural elements in English language teaching materials (Nagy, 2018); integrating materials based on global issues into the development of professional soft and hard skills (Diachkova, Sazhko, Shevchenko \& Syzenko, 2021); articles, books, seminars, lectures and workshops (Yang, 2010); reading a variety of authentic texts, viewing movie and video clips, group discussions, and working on group projects (Tseng, 2017); reading multicultural short stories in EFL classes (Tural \& Cubukcu, 2021; Al-Jarf, 2016; AlJarf, 2015); virtual exchange in which students are connected with students from different lingua-cultural backgrounds over extended periods of time via digital communication technologies (Krengel, 2021; Al-Jarf, 2020b; Al-Jarf, 2006a; Al-Jarf, 2006b; Al-Jarf, 2006c); combining content-based, task-based and communicative language teaching methods (Omidvar \& Sukumar, 2013; Al-Jarf, 2021f; Al-Jarf, 2005b); multicultural counseling training (Zhang, Cui \& Zhang, 2021); using an ethnographic teaching methodology (Aubrey, 2009); intercultural teaching with films (Liu, 2020); use of a variety of technologies such as online courses, mobile apps, online discussion forums, blogs, web-conferencing software such as Elluminate, online videos, mind-mapping software, and online SMS (Jiang, Soon \& Li, 2021; Al-Jarf, 2022a; Al-Jarf, 2022b; Al-Jarf, 2021b; Al-Jarf, 2021d; Al-Jarf, 2021i; Al-Jarf, 2020c; Al-Jarf, 2014a; Al-Jarf, 2014b; Al-Jarf, 2012a; Al-Jarf, 2012b; Al-Jarf, 2006a; Al-Jarf, 2006b; Al-Jarf, 2006c; Al-Jarf, 2005a).

Despite the importance of integrating cultural issues and materials in language learning, there is still a need for creating global and intercultural awareness among students in numerous countries. Aubrey (2009) pointed out that there is a need to create a cultural awareness among EFL students in Japan. In China, Liu (2020) called for the integration of intercultural education in EFL and revealed the urgent need for research on how teachers can be equipped with intercultural teaching skills to be able to carry out activities that will help enhance students' intercultural communicative competence. Cultural background knowledge deficiency strongly affects English learning. Lack of cultural awareness and insufficient cultural background knowledge directly obstruct EFL college students' learning competence in English (Wang, 2018). Therefore, it is of great importance to enhance students' cultural awareness and develop their background knowledge about the target culture. In Saudi Arabia, a study by Alsamani (2014) showed that English language majors need to learn about different aspects of the foreign culture to develop their cultural awareness. The researcher recommended the integration of culture in EFL courses.

Moreover, the literature review showed lack of studies in Saudi Arabia, that explore whether global themes are integrated in EFL instruction, in general, and reading and speaking instruction, in particular. Therefore, this study aims to find out whether EFL instructors at Saudi universities integrate global themes in the EFL courses that they teach and the kinds of global themes that they integrate in extensive reading and speaking activities. The study also proposes a model for integrating global themes in EFL reading and speaking classrooms. It will give the types of global themes that can be 
integrated in EFL reading and speaking extensive activities, and how they can be integrated. It will describe the instructional phases with global themes, in addition to the instructor's role in EFL integrating global themes in reading and speaking extensive activities.

This study is significant for developing EFL Saudi students' reading and speaking skills and raising their global awareness. It will help EFL students learn about the cultures and customs of other countries; address global problems; compare the similarities and differences that peoples of the world share; analyze international organization; focus on the interrelatedness of human beings; recognize stereotypes about other cultures; and listen to multiple perspectives.

\section{METHODOLOGY}

\subsection{Participants}

A total of 47 EFL instructors teaching language, translation, linguistics, and literature courses at five Saudi universities (Princess Noura University, King Saud University, King Abdul-Aziz University, Imam University and King Khalid University) participated in the study. The instructors have a Ph.D. and/or an M.A. degree in TESO1, applied linguistics, linguistics, or literature. They teach different English language courses, with a focus on those who teach reading and speaking. The participants have different years of experience.

\subsection{Instrument}

To find out whether EFL instructors in the sample integrate global themes in the EFL courses that they teach to EFL college students, a questionnaire with open-ended questions was developed and administered to all the participants via WhatsApp and Facebook Messenger. The questions asked the participants whether they integrate global themes in reading and speaking courses, to give examples of global themes that they select and use (if any), and to give reasons why they integrate or do not integrate global themes in the courses they teach.

\subsection{DATA ANALYSIS}

Instructors' responses to the questionnaire were compiled, sorted out and analyzed qualitatively and quantitatively. The percentages of instructors who integrate and those who do not integrate global themes in EFL reading and speaking courses that they teach were computed.

\section{RESULTS}

Analysis of the participants' responses to the questionnaire showed that all of the participants in the sample do not integrate any global themes in the listening, speaking, reading, or writing courses that they teach. They just use the textbooks assigned by their departments. They do not know which global topics to integrate, or how to integrate global topics in EFL instruction. They believe that global topics are difficult for EFL freshman students to talk, read or write about. They only focus on the topics included in the assigned textbooks.

\section{THE PROPOSED MODEL}

\subsection{Which Global Themes to Integrate}

According to Kniep (1986), there are 4 areas of global themes that can be integrated in EFL reading and speaking classrooms: (i) Global systems; (ii) Diverse human values; (iii) Global problems and issues; and (iv) World history. Al-Jarf (2020a), A-Jarf (2007), Al-Jarf, 2006d; Al-Jarf (2003a) and Al-Jarf (2003b) expanded and operationalized the four aspects of global themes as follows:

\section{1) Gobal Systems}

- Cultural: Folk tales, costumes, music, folklore dance, ethnic food, holidays, houses, worshiping houses, sports, games, medical treatment, children's literature, arts, consumer society, cultural pluralism.

- Ecological: Pollution, oil spills, waste disposal, deforestation, forest fires, endangered species, global weather changes, global warming, land reclamation, managing water resources, protection the environment, desertification, natural disasters, earthquakes, tsunamis, volcanoes.

- Economic: The new global economic system, economic problems, economic development, causes of economic backwardness, requirements of economic progress, tourism, small businesses, new monetary system, bitcoin, oil and energy, global markets, stock market, International Monetary Fund, World Economic Forum, WTO, World Bank, Multinational companies

- Political: Democracy, political changes, new global political systems, unipolarity, relationship between developed and underdeveloped countries, foreign relations, NATO, African League, Afghanistan, Arab spring.

- Health Systems: health care, infant fatality, infectious diseases, the Covid-19 Pandemic, Health problems, drug abuse.

- Educational systems: Higher education, vocational education, distance education, illiteracy, continuing education, e-learning. 
- International Organizations: UN, UNESCO, UNICEF, WHO, Amnesty International, World Court.

- Technological Systems: e-books, internet, telecommunications, satellite T.V., newsgroups, digital technology, mobile phones, language learning mobile apps, digital cameras, YouTubers, TikTok, Instagram, social media, WhatsApp.

- Social Systems: social security, elderly care, handicapped, delinquents, children's rights, social changes, Earth Summit, social classes, working women, status of women, family systems, Children's Day, women liberation movements.

- Ideological \& Judicial Systems: world religions, religious minorities, injustice, conflict among civilizations, human rights, worshipping houses, ethnicity, sectarianism.

2) Current Global Issues: World peace, terrorism, violence, famines, hunger, poverty, earthquakes, immigrants, child labor, refugees, conflict among religions, civil wars, drug addiction, the homeless, housing problems, crowdedness, biodiversity, sustainable development, refugees in Europe.

3) Diverse human values: Conflict resolution, cooperation, teamwork, responsibility, participation, including others, volunteer work, relief work, respecting differences, solidarity, recognizing oneself, appreciating national and ethnic heritage, adaptability, self-pride.

4) World history of contact and interdependence among peoples: cultures, and nations, historical relations, ancient civilizations, immigration, major wars, colonization, liberation movements, expeditions, history of science and technology, The Industrial Revolution, political revolutions, history of languages, conflicts in the 21 st century.

\subsection{Which Objectives to Integrate}

According to Boocker and Others (1985) and Collins, Czarra and Smith (1996), and Al-Jarf (2021g), there are 4 types of objectives associated with the integration of global issues in education:

- Knowledge Objectives include facts, concepts, generalizations that students should acquire through the global themes.

- Skills objectives refer to ability to collect, organize, synthesize, analyze, relate, interpret, apply info; transfer of learning; critical thinking; problem-solving; reading skills; writing skills; oral communication skills; computer skills.

- Value objectives refer understanding, cooperation, accepting difference, teamwork

- Participation goals refer to students' involvement in social issues and problems.

\subsection{Which Global Concepts to Focus On}

Examples of global concepts related to global issues that can be focused on while reading and speaking are understanding, cooperation, acceptance, otherness, competition, solidarity, exchange, integration, unity, terrorism, antiterrorism, peace, the peace process, settlement, dialogue, negotiations, stability, legitimacy, conflict, conflict resolution, aggression, hatred, resentment, rejection, racism, tolerance.

\subsection{Locating Material about Global Themes}

The global topics selected should be current, familiar, tangible, specific and widespread. They should be related to what the students watch on TV, or on YouTube, mobile apps, audio books, online newspapers, news websites (CNN, BBC, Aljazeera) and what they read on social media such as Twitter, Facebook, Instagram, and others. A chosen global theme can be personalized by having the students speak about their views, experience, and reactions. Broad topics can be broken down into specific ones. When students read about a global topic, they should be able to identify the main ideas and supporting details such as definitions, what happened, when, where, why, how, and the outcomes. When they speak, they should be able to present a summary, give a presentation or report on the global topic, talk about their reactions to it and propose a solution to the global problem or issue. The instructor can select and assign global themes such as climate change, pollution, malnourishment and hunger, security and wellbeing, violence, unemployment, lack of education, government corruption, substance abuse, terrorism, issues of peace, human rights, the environment, women and education (Al-Jarf, 2006d). The students can also propose articles, videos or apps related to a global theme of interest to them.

\subsection{Instructional Phases with Global Themes}

According to Al-Jarf (2005), EFL reading and speaking instruction with global themes goes through three phases. In the Pre-task Phase, the instructor introduces the students to the global theme under study. She tells the students what they will read or speak about, and how the activity will be performed (individually, in pairs or in small groups; from the classroom or home, i.e., synchronously, or asynchronously). They can use their laptop, smart phone, tablet, or iPad. She selects a Learning Management System such Blackboard, Zoom, Microsoft Teams, Google Meet or WeEx, an online discussion forum, a blog, or a page on social media such as Twitter or Facebook, where questions, 
answers, discussions, feedback, and notifications are posted. Every week or so, she assigns a new global topic. The students can search Google or any other source for articles, podcast, news story, or videos related to the assigned global topic. The instructor can integrate participation goals that focus on students' involvement in the global issue selected. The students can describe the global problem, diagnose it, and propose solutions for it (Al-Jarf, 2021g). The instructor gives clear, direct, and specific instructions for reading and speaking about the topic.

In the Task Phase, the students brainstorm the topic individually, in pairs or small groups by asking "what, who, whom, where, why, how, when" about the global topic. Vocabulary items, grammatical structures, or functions related to the global topic that the students might encounter in the article or video can be explained by the instructor before they read the article or watch the video. After brainstorming, the students can answer comprehension questions about the main ideas and supporting details in the assigned article. They can summarize the article or content of the video orally or in writing, or react to it. They may give a presentation or a report about the topic for few minutes. They can comment or react to the content. Summaries, answers, and reactions can be posted on the technology selected.

In the Post-task Phase, the students discuss their answers to the comprehension questions or make comments on each other's speaking tasks or presentations. One or two types of grammatical errors may be identified and corrected by the students each time a global topic is assigned. The instructor comments on common errors and weaknesses and gives feedback on areas of improvement. For the following class or following week's task, she assigns a new global topic and gives instructions to help the students brainstorm prior to the reading or speaking tasks.

\subsection{Instructor's Role}

Extensive reading and speaking activities with global themes should be student-centered, not instructorcentered. The instructor serves as a facilitator. She can select the global themes, articles, videos, or mobile apps, encourage the students to choose any global theme, any article, video, podcast, or app related to a global theme that they like. She encourages the students to participate, interact, comment and give feedback. She moderates the class discussion and comments. She responds to reading and speaking problems, answers questions, and provides help. She gives a deadline for working on the reading and speaking tasks. Links to reading material or YouTube videos, study skills and self-improvement tips can be posted. The instructor should always encourage the students, thank them for their efforts and can give them extra marks for participating in each global topic regardless of the quality of their performance to encourage them to participate and work on the tasks.

\section{RECOMMENDATIONS}

The integration of global themes in extensive EFL reading and speaking activities are beneficial to students' reading and speaking skill development. Therefore, to make the best use of global themes in EFL teaching and learning, the present study recommends that EFL instructors match the global topics' difficulty level, complexity, and relevance with the student's proficiency level in EFL.

In addition, the students can engage in problem-solving and project-based topics or hosting a professional to talk about a global issue. Then they can summarize the content of the interview or speech, prepare a summary, a presentation, or a report about it or react to the content (Al-Jarf, 2021e; Al-Jarf, 2021f). The students and their instructor can use mindmaps to connect and show relationships among main ideas and supporting details in an article or video that the students have read or watched about the global topic (Al-Jarf, 2021i).

The students can be encouraged to gather information about certain global topics such as the Coronavirus Pandemic to construct a picture about its real situation, people infected with it, causes of the pandemic, prevention and treatment, and effects of the pandemic on people's daily life. They can collaborate with EFL students in other countries, share a blog forum, web-conferencing technology such as Skype to talk about problems of distance learning during the Pandemic and how they were solved, build up a picture of the Covid-19's real situation, people infected with it, causes of the pandemic, prevention and treatment, and effects of the pandemic on people's daily life. Students and instructors from different backgrounds may enter into a dialogue with each other using a blog, online discussion forum or social media page to gain knowledge of the reality of Coronavirus Pandemic or distance learning, and reflect on them critically (AlJarf, 2021c; Al-Jarf, 2020b; Al-Jarf, 2006c).

The EFL instructor can integrate mobile books, ebooks or audiobooks about global topics and use collaborative reading activities, a combination of reading and writing activities, speaking, and writing activities, and/or listening and speaking activities about the global topics in them. The students can use the audiobook and the activities collaboratively, then summarize the content, answer comprehension questions, or reflect on the content orally or in writing (Al-Jarf, 2021b; Al-Jarf, 2021h).

The students may read and speak about employment, unemployment, or economic issues during the Coronavirus Pandemic in the Kingdom and other countries around the world (Al-Jarf, 2022c). They may also watch TED Talks about 
global topics either live, on YouTube or on their smart phones and give an oral summary or their reaction to it (Al-Jarf, $2021 \mathrm{j}$ ).

A social media page such as a Facebook or Twitter page can be utilized to post articles or videos that show hate racism speech or discrimination against certain groups of people, summarize, speak about, react to the information in them and propose solutions (Al-Jarf, 2021c).

To correct students' reading comprehension and speaking errors, the instructor gives communicative feedback that focuses on meaning/idea and highlights only errors that are common among the group. She provides feedback on the location of grammatical errors, but no correct forms are given. The students correct themselves and correct each other's errors. Extra credit is given for good blogposts every time the students post a paragraph in the blog (Al-Jarf, 2021a).

Furthermore, EFL instructors should take into consideration that use of a particular technology and selecting a global theme, no matter how interesting, current, and specific it is, does not guarantee students' reading and speaking skill development. It all depends on how the technology is used, the kinds of tasks required, amount of reading and speaking performed, teacher's guidance, and encouragement.

Finally, instructors teaching different reading and speaking courses to students in different levels at the same department or at different universities in Saudi Arabia may collaborate and share certain global themes and a particular technology where students can meet, discuss, interact, and collaborate. Using global themes in reading, speaking, writing and translation courses and using social media such as Facebook to listen to, read, write, and speak about global themes are still open for further investigation in the future.

\section{Funding}

This research received no external funding. It was funded by the author.

\section{Conflicts of Interest}

The authors declare no conflict of interest.

\section{REFERENCE}

- A-Jarf, R. (2007). Integrating global culture in EFL college materials. 7th Annual English Language Teaching Conference. Sultan Qaboos University, Muscat, Oman. April 18-19.

- Al-Jarf, R. (2005a). Connecting students across universities in Saudi Arabia. 4th Asia CALL Conference. ERIC ED497940.

- Al-Jarf, R. (2006b). Impact of online instruction on EFL students' cultural awareness. ERIC ED497400.

- Al-Jarf, R. (2012a). Mobile technology and student autonomy in oral skill acquisition. In Javier E. Díaz Vera’s Left to My Own Devices: Innovation and Leadership in English Language Teaching. 105-129. Brill. DOI: 10.1163/9781780526478_007

- Al-Jarf, R. (2015). Enhancing reading and speaking skills in EFL through multicultural children's short stories. 7 th International Conference, Building Cultural Bridges (ICBCB) titled: Integrating Languages, Linguistics, Literature, Translation, and Journalism into Education.Suleyman Demire IUniversity, Almaty, Kazakhstan. April 23-24. DOI: 10.2139/ssrn.3848464. ERIC ED610158.

- Al-Jarf, R. (2020a). A model for a global education course for Saudi junior and senior high schools. Eurasian Arabic Studies, 11, 76-97. DOI: 10.26907/2619-1261

- Al-Jarf, R. (2021g). Integrating participation goals in writing activities for EFL college students. Journal for Research Scholars and Professionals of English Language Teaching (JRSP-ELT), 23(5). ERIC ED613141. https://www.jrspelt.com/wp-content/uploads/2021/01/R. -Writing-Activities.pdf

- Al-Jarf, R. (2021h). Mobile audiobooks, listening comprehension and EFL college students. International Journal of Research - GRANTHAALAYAH, 9(4), 410-423. DOI: 10.29121/granthaalayah.v9.i4.2021.3868. DOI: $10.2139 / \mathrm{ssrn} .3841694$

- Al-Jarf, R. (2021i). Teaching reading to EFL freshman students with mind-mapping software. Journal for Research Scholars and Professionals of English Language Teaching (JRSP-ELT), 24(5), 1-12. DOI: 10.2139/ssrn.3825817

- Al-Jarf, R. (2003a). Global themes in Singaporean secondary social studies textbooks. Curriculum Development Conference Titled: Principles and Starting Points. Vol. 2, pp. 921-950. College of Education, King Saud University.

- Al-Jarf, R. (2003b). The global dimension in Saudi history textbooks for grades 4-12. Curriculum Development: Principles and Starting Points Conference, May 13-14. Vol I, 101-132. College of Education, King Saud University. Riyadh, Saudi Arabia.

- Al-Jarf, R. (2005b). Task-based instruction for EFL struggling college writers. International. Conference on TaskBased Language Teaching (TBLT 2005). Centre for Language and Migration, University of Leuven, Belgium. 
- Al-Jarf, R. (2006a). Cross-cultural communication: Saudi, Ukrainian, and Russian students online. Asian EFL Journal, 8(2), June. ERIC ED489964.

- Al-Jarf, R. (2006c). Using online dialogue to develop cross-cultural understanding. Iranian Journal of Linguistic Studies (IJLS), 1,13-25. ERIC ED494790.

- Al-Jarf, R. (2006d). Women, Gender and national curricula: Gulf and Saudi Arabia. In S. Joseph (Ed.), Encyclopaedia of Women and Islamic Cultures (EWIC). (vol. IV, p. 32). Koninklijke Brill NV. The Netherlands.

- Al-Jarf, R. (2012b). Online videos for specific purposes. 2nd International Conference on Human and Social Sciences ICHSS 2012) - Tirana, Albania. March 23-24, volume 7, 15-19. https://www.researchgate.net/publication/346658486. DOI: 10.5901/ichss-2012-vol-07.

- Al-Jarf, R. (2014a). Integrating Elluminate in EFL reading instruction. The 10th International Conference on eLearning and Software for Education (eLSE). 3, 19-26. Bucharest, Romania. DOI: 10.12753/2066-026X-14-142.

- Al-Jarf, R. (2014b). Integrating ethnic culture Facebook pages in EFL instruction. In M. V. Makarych (Ed.), Proceedings of the International Scientific Conference on "Ethnology: Genesis of Hereditary Customs" Belarusian National Technical University (BNTU), Minsk, Belarus. DOI: 10.2139/ssrn.3848464.

- Al-Jarf, R. (2016). Enhancing reading and speaking skills in EFL through multicultural children's short stories. Asian Academic Journals of Social Sciences and Humanities (AAJSSH), 3(7) (July), 288-298. DOI: 10.2139/ssrn.3848464 https://www.researchgate.net/publication/358511293

- Al-Jarf, R. (2020b). Building cultural bridges through social media networks: a case study. Global Trends and Values in Education, 1(1), 81-106. ERIC ED613111. https://journals.sdu.edu.kz/index.php/gtve/issue/current.

- Al-Jarf, R. (2020c). Mobile apps in the EFL college classroom. Journal for Research Scholars and Professionals of English Language Teaching (JRSP-ELT), 4(22), 1-5. ERIC ED613138.

- Al-Jarf, R. (2021a). A model for communicative error correction in Saudi EFL freshman students' writing. $i$ manager's Journal on English Language Teaching, 11(2), 32-41. DOI: 10.26634/jelt.11.2.17719

- Al-Jarf, R. (2021b). Collaborative mobile ebook reading for struggling EFL college readers. IOSR Journal of Research and Methods in Education, 11(6), 32-42. https://www.iosrjournals.org/iosr-jrme/papers/Vol-11\%20Issue6/Ser 2/D1106023242.pdf. DOI: 10.9790/7388-1106023242.

- Al-Jarf, R. (2021c). Combating the Covid-19 hate and racism speech on social media. Technium Social Sciences Journal, 18, 660-666. DOI: 10.47577/tssj.v18i1.2982

- Al-Jarf, R. (2021d). Connecting university students, faculty, and administrators through an online SMS Service. Journal La Sociale, 2(4), 1-8. DOI. 10.37899/journal-la-sociale.v2i4.448

- Al-Jarf, R. (2021e). EFl speaking practice in distance learning during the coronavirus pandemic 2020-2021. International Journal of Research - GRANTHAALAYAH, 9(7), 179-196. 10.29121/granthaalayah.v9.i7.2021.4094. ERIC ED615084.

- Al-Jarf, R. (2021f). How instructors engage students in distance learning during the Covid-19 second wave. 26th Annual TCC Worldwide Online Conference. Hawaii, USA. April 13-14, 2021. https://www.researchgate.net/profile/Reima-Al-Jarf/publication/357826530

- Al-Jarf, R. (2021j). TED Talks as a Listening Resource in EFL College classrooms. International Journal of Language and Literary Studies (ijlls), 2(3), 256-267. DOI: 10.36892/ijlls.v2i3.691. https://ijlls.org/index.php/ijlls/article/view/691 ERIC Number: ED615127

- Al-Jarf, R. (2022a). Blogging About Current Global Events in the EFL Writing Classroom: Effects on Skill Improvement, Global Awareness and Attitudes. British Journal of Teacher Education and Pedagogy, 1(1), 73-82. DOI: $10.32996 /$ bjtep.2022.1.1.8

- Al-Jarf, R. (2022b). Blogging about the Covid-19 pandemic in EFL writing practice. Journal of Learning and Development Studies (JLDS), 2(1), 1-8. DOI: 10.32996/jlds.2022.2.1.1

- Al-Jarf, R. (2022c). The pandemic job market from the perspective of female languages and translation college graduates in Saudi Arabia: Crisis or opportunity. In: Rocha A., Isaeva E. (eds) Science and Global Challenges of the 21st Century - Science and Technology. Perm Forum 2021. Lecture Notes in Networks and Systems, vol 342, 720-733. Springer, Cham. DOI: 10.1007/978-3-030-89477-1_68

- Alsamani, A. (2014). Foreign culture awareness needs of Saudi English language majors at Buraydah community college. English Language Teaching, 7(6), 143-153.

- Aubrey, S. (2009). Creating a global cultural consciousness in a Japanese EFL classroom. English Language Teaching, 2(2), 119-131.

- Bayraktar Balkir, N. (2021). Uncovering EFL learners' perspectives on a course integrating global issues and language learning. Novitas-ROYAL (Research on Youth and Language), 15(1), 118-133.

- $\quad$ Boocker, S. \& Others (1985). Social studies curriculum, K-8. ERIC ED285817.

- Collins, H., Czarra, F., \& Smith, A. (1996). Guidelines for global and international studies education: challenges, culture, connections. Issues in Global Education; June- July, 135,136. 
- DeLoach, S., Kurt, M., Olitsky, N. (2015). Does content matter? Analyzing the change in global awareness between business- and nonbusiness-focused short-term study abroad courses. Journal of Teaching in International Business, 26(1), 4-31.

- Diachkova, Y., Sazhko, L., Shevchenko, L. \& Syzenko, A. (2021). Global issues in ESP classroom: challenges and opportunities in higher education. Arab World English Journal, 12(1), 388-400.

- Gertsenzon, G. (2021). Bridging the interval: teaching global awareness through music and politics. Journal of the National Collegiate Honors Council, 22(1), 135-167.

- Hayati, A. (2009). The impact of cultural knowledge on listening comprehension of EFL learners. English Language Teaching, 2(3), 144-152.

- Jiang, Q., Soon, S. \& Li, Y. (2021). Enhancing teachers' intercultural competence with online technology as cognitive tools: A literature review. English Language Teaching, 14(3), 1-11.

- Kniep, W. (1986). Defining a global education by its content. Social Education; 50(6), 437-46.

- Krengel, F. (2021). Glocal education" through virtual exchange? training pre-service EFL teachers to connect their local classrooms to the world and back. Global Education Review, 8(2-3), 138-153.

- Liu, F. (2020). Intercultural language teaching practice in EFL classroom China--college English instruction based on film "the proposal". English Language Teaching, 13(12), 83-90.

- $\quad$ Lopez, T., Kemp, A. \& McKenzie, R. (2019). Building authentic intercultural awareness in the business classroom. Journal of International Education in Business, 12(2), 198-211.

- Medina, A. \& Kiefel, K. (2021). Global literature in tandem with study abroad: cultivating intercultural competence for preservice teachers. Frontiers: The Interdisciplinary Journal of Study Abroad, 33(2), 61-78.

- Nagy, G. (2018). Towards intercultural competence: Models and frameworks for developing ESOL learners' intercultural competence in Ireland. International Online Journal of Education and Teaching, 5(3), 649-660.

- Omidvar, R. \& Sukumar, B. (2013). The effects of global education in the English language conversation classroom. English Language Teaching, 6(7), 151-157.

- Tseng, C. H. (2017). Teaching "cross-cultural communication" through content-based instruction: Curriculum design and learning outcome from EFL learners' perspectives. English Language Teaching, 10(4), 22-34.

- Tural, P. \& Cubukcu, F. (2021). Raising intercultural awareness through short stories in EFL Classes. Journal of Educational Sciences, 22, 1(43), 18-32.

- Wang, G. (2018). On the strategies of enhancing students' cultural awareness in college English teaching. English Language Teaching, 11(12), 116-120.

- Welton, G. L. (2021). Expanding long-term global awareness and cultural sensitivity at a rural Christian college. Christian Higher Education, 20(3), 125-140.

- Yang, Y. (2010). Interactive cultural cultivating in FLT. English Language Teaching, 3(1), 28-31.

- Zhang, H., Cui, L. \& Zhang, X. (2021). Multicultural awareness and foreign language learning among Chinese college students: A one-year longitudinal investigation. International Journal of Multilingualism, 18(3), 370-383.

- Zhu, H. (2011). From intercultural awareness to intercultural empathy. English Language Teaching, 4(1), 116-119. 